\title{
Pengaruh Aplikasi Beberapa Konsentrasi Paclobutrazol dan KOH Terhadap Pertumbuhan dan Produksi Tanaman Ubi Kayu (Manihot esculenta crantz)
}

\section{The Effect of Application Some Concentrate Paclobutrazol and $\mathrm{KOH}$ Growth and Production of Cassava}

\author{
Ardian*, Prasasti Aritonang, dan Kukuh Setiawan \\ ${ }^{1}$ Jurusan Agroteknologi, Fakultas Pertanian, Universitas Lampung \\ Jln. Soemantri Brodjonegoro 1, Bandar Lampung 35145 \\ *E-mail: ardian.unila@gmail.com.
}

\begin{abstract}
This study aimed to evaluate the effect of paclobutrazol and $\mathrm{KOH}$ application through the leaf to growth and production of cassava. This study was conducted from March 2017 to October 2018 at an Integrated Field University of Lampung. The treatments were arranged factorially $(4 \times 4)$ in a complete randomized block design with 4 replications be avowed as a group. The main factor were paclobutrazol consist of $P 1=0 \mathrm{ppm}$ (control, no treatment), $P 2=400 \mathrm{ppm}, P 3=500 \mathrm{ppm}$ and $\mathrm{P} 4=600 \mathrm{ppm}$. The second factor were $\mathrm{KOH}$ consist of $K 1=0 \%$ (control, no treatment), $K 2=0,5 \%, K 3=1 \%$ and $K 4=1,5$ given a week after paclobutrazol's application. This study used cassava cutting varieties of kasesart. Observation variables were plant height, number of books, number of fresh leaves, fresh weight of leaves, dry weight of leaves, fresh weight of stem, dry weight of stem, fresh weight of tubers, dry weight of tubers. Data of each treatment were calculated its mean value and tested homogeneity. Homogeneous data were analyzed variance and followed by the smallest real difference test level 5\%. The study's result showed that paclobutrazol application had inhibited affect the vegetative growth of plant height, number of nodes, fresh and dry weight of stem cassava plants. Application of KOH had a significant effect only on the number of fresh leave at 13 weeks after planted. The interaction of paclobutrazol and $\mathrm{KOH}$ treatment had a significant effect on leaf dry weight.
\end{abstract}

Keywords: Cassava, KOH, inhibition, paclobutrazol, production

Disubmit : 03 Juni 2019; Diterima: 14 Agustus 2019 ; Disetujui : 28 Oktober 2019

\section{PENDAHULUAN}

Ubi kayu (Manihot esculenta Crantz) atau singkong merupakan salah satu komoditi tanaman pangan tergolong umbi-umbian yang mengandung karbohidrat sebesar 34,7\% (Soetanto, 2001). Ubi kayu dapat memenuhi 50\% kebutuhan kalori total atau 90\% kebutuhan kalori dari karbohidrat bagi penduduk di negaranegara Afrika Tengah. Di Indonesia ubi kayu dapat memenuhi $15 \%$ kebutuhan kalori total atau $31 \%$ kebutuhan kalori dari karbohidrat (Simanjuntak, 2006). Produksi ubi kayu di Indonesia sebagian besar digunakan untuk memenuhi kebutuhan dalam negeri (85-90 persen) yaitu 71,69\% sebagai bahan pangan (langsung atau melalui proses pengolahan), 13,63 \% untuk keperluan industri non pangan, 2,00 persen untuk pakan, dan 12,66\% terbuang (sisa di lahan pertanian) dan diekspor dalam bentuk gapleks, chips dan tepung tapioka (Hafsah, 2003). 
Salah satu cara meningkatkan produksi ubi kayu adalah dengan intensifikasi yaitu penggunaan zat pengatur tumbuh seperti paclobutrazol yang dapat menghambat pertumbuhan vegetatif sehingga lebih cepat memasuki fase generatif dan umur panen lebih singkat. Paclobutrazol merupakan zat pengatur tumbuh yang dapat menghambat pertumbuhan, menyebabkan tanaman kerdil, meningkatkan kandungan klorofil daun sehingga aktifitas fotosintesis dapat berjalan dengan baik, dan meningkatkan produksi dan menghambat sintesis giberelin (Salisbury, 2002). Pemberian paclobutrazol mampu meningkatkan produksi ubi namun dapat menyebabkan dormansi tunas. Aplikasi paclobutrazol pada tanaman mangga menyebabkan mata tunas menjadi dorman, dan pecah tunas dapat terjadi beberapa bulan setelah aplikasi paclobutrazol. Pemberian etephon, BAP atau KNO3 dapat mempercepat pecah tunas dan pembentukan bunga (Poerwanto, R, Harjadi, SS, Susanto, S, Purwoko, BS, Widodo, WD \& Effendi, 1995).

Pada penelitian ini, zat pemecah dormansi yang diberikan adalah $\mathrm{KOH}$. Mekanisme penyerapan kalium melalui $\mathrm{KOH}$ pada tanaman diduga sama dengan $\mathrm{KNO} 3$ yaitu kalium dalam bentuk ion $\mathrm{K}+$ bersifat sebagai aktivator enzim yang berperan dalam proses metabolisme untuk membentuk karbohidrat (pati) dan protein. Karbohidrat dan protein yang terbentuk akan digunakan untuk aktivitas pembelahan, pembesaran, dan pemanjangan sel. Penelitian dengan menggunakan larutan $\mathrm{KOH}$ sebagai zat pemecah dormansi pada tanaman baru pertama kali dilakukan sehingga keterangan mengenai penggunaan $\mathrm{KOH}$ masih sedikit.

Beberapa penelitian melaporkan bahwa pemberian $500 \mathrm{ppm}$ paclobutrazol lewat daun merupakan konsentrasi optimum dalam menghambat pertumbuhan tanaman ubi kayu. Pada konsentrasi tersebut pertumbuhan vegetatif tanaman terhambat dilihat dari lambatnya proses penambahan tinggi tunas jika dibandingkan dengan perlakuan lainnya (Yuliadi, E., Sunyoto., Kristina, 2011). (Runtunuwu, S. D., P. Tumewu, D.M.F. Sumampouw, S. Walingkas, 2013) menyatakan bahwa aplikasi paclobutrazol dengan konsentrasi 400 ppm sampai 600 ppm dapat digunakan untuk menghasilkan tanaman padi yang pendek dengan produktivitas yang lebih tinggi. Tujuan penelitian adalah mengevaluasi pengaruh pemberian paclobutrazol dan $\mathrm{KOH}$ melalui daun terhadap pertumbuhan dan produksi ubi kayu.

\section{METODE PENELITIAN}

Penelitian ini dilaksanakan di Lapangan Terpadu Universitas Lampung dengan jenis tanah ultisol, yang sebelumnya digunakan untuk budidaya tanaman ubi kayu. Waktu penelitian yaitu dari bulan Maret sampai Oktober 2017. Penelitian dilaksanakan dalam Rancangan Acak Kelompok (RAK) dengan 4 ulangan yang digunakan sebagai kelompok. Perlakuan disusun secara faktorial (4 x 4) dengan faktor pertama adalah paclobutrazol terdiri dari empat taraf, yaitu 0 ppm (P1) sebagai kontrol, 400 ppm (P2), 500 ppm (P3), dan 600 ppm (P4). Faktor kedua adalah KOH terdiri dari empat taraf, yaitu 0\% (K1), 0,5\% (K2), $1 \%(\mathrm{~K} 3), 1,5 \%$ (K4). Volume pemberian per tanaman adalah $50 \mathrm{ml}$ dan sebelum aplikasi dilakukan pemotongan shoot tip yang tepat berada di pucuk tunas.

Penelitian ini dilakukan dengan menggunakan bahan tanam stek batang tanaman ubi kayu klon Kasetsart. Tanah seluas 16x10 m diolah menggunakan cangkul, kemudian dipupuk dengan pupuk kandang ayam sebanyak $320 \mathrm{~kg}$. Stek dengan ukuran $25 \mathrm{~cm}$ ditancapkan pada media tanam berupa guludan yang telah diolah dengan posisi tegak dan $1 / 3$ bagian berada di dalam tanah. Jarak tanam antarstek dalam barisan adalah 0,8 m sedangkan jarak antar guludan/ antarbaris (ulangan) adalah $1 \mathrm{~m}$. Jumlah stek yang ditanam adalah 220 stek. Setiap stek perlakuan yang telah diacak diberi label sebagai penanda sesuai dengan jumlah perlakuan dan ulangan untuk memudahkan dalam aplikasi perlakuan.

Pemupukan dilakukan dengan memberikan pupuk anorganik yaitu Urea, TSP dan KCL. Aplikasi paclobutrazol dilakukan pada pagi hari dua BST (60 hari setelah tanam). Kebutuhan pupuk untuk tanaman ubi kayu adalah Urea $100 \mathrm{~kg} / \mathrm{ha}$, TSP $100 \mathrm{~kg} / \mathrm{ha}$, KCL $200 \mathrm{~kg} / \mathrm{ha}$ dan untuk per tanaman adalah Urea $5 \mathrm{~g}$, TSP 5 g, dan KCL 10 g. Pemupukan diberikan 2 kali dengan cara ditugal sekitar $7 \mathrm{~cm}$ dari stek tanaman dengan dosis pupuk yang diberikan 2 minggu setelah tanam (MST) adalah 2 g Urea, 5 g TSP dan 3 g KCl 
per tanaman. Pemupukan kedua dilakukan pada 2 bulan setelah tanam (BST) dengan dosis $3 \mathrm{~g}$ Urea, dan $7 \mathrm{~g}$ $\mathrm{KCl}$ per tanaman.

Paclobutrazol diberikan dengan cara disemprotkan ke daun terutama pada bagian pucuk, dan bagian bawah daun dengan menggunakan sprayer sebanyak $50 \mathrm{ml}$. Seminggu kemudian, aplikasi KOH dilakukan dengan cara yang sama dengan aplikasi paclobutrazol. Pengamatan dilakukan setiap minggu dengan mengukur tinggi tanaman, menghitung jumlah buku, jumlah daun segar dimulai dari seminggu sebelum aplikasi paclobutrazol. Lima bulan setelah tanam (BST) dilakukan pemanenan dan menghitung bobot brangkasan segar dan kering daun, batang dan ubi.

Data pada masing-masing perlakuan dihitung nilai tengahnya dan diuji homogenitas. Data yang sudah homogen dianalisis ragam dilanjutkan dengan uji lanjut beda nyata terkecil (BNT) pada taraf 5\%.

\section{HASIL DAN PEMBAHASAN}

Pengamatan dari hasil analisis ragam dan peubah dari berbagai berbagai konsentrasi paclobutrazol dan KOH pada pertumbuhan tanaman ubi kayu untuk setiap variabel pengamatan pada Tabel 1.

Tabel 1. Rekapitulasi hasil analisis ragam pengaruh berbagai konsentrasi paclobutrazol dan KOH pada pertumbuhan tanaman ubi kayu untuk setiap variabel pengamatan.

\begin{tabular}{lccc}
\hline Variabel Pengamatan & Paclobutrazol & KOH & PxK \\
\hline Tinggi Tanaman 13 mst & $*$ & tn & tn \\
Tinggi Tanaman 15 mst & $*$ & tn & tn \\
Jumlah Buku 13 mst & $*$ & tn & tn \\
Jumlah Buku 15 mst & $*$ & tn & tn \\
Jumlah Daun Segar 13 mst & tn & tn & tn \\
Jumlah Daun Segar 15 mst & tn & tn & tn \\
Bobot Basah Daun & tn & tn & $*$ \\
Bobot Kering Daun & $*$ & tn & tn \\
Bobot Basah Batang & $*$ & tn & tn \\
Bobot Kering Batang & tn & tn & tn \\
Bobot Basah Ubi & tn & tn & tn \\
Bobot Kering Ubi & &
\end{tabular}

Keterangan: $*$ = berpengaruh nyata pada $\alpha=5 \%$;

$\mathrm{tn}=$ tidak berpengaruh nyata pada $\alpha=5 \%$;

$\mathrm{mst}=$ minggu setelah tanam

Tinggi Tanaman. Pengamatan dari hasil nilai tengah dari aplikasi beberapa konsentrasi paclobutrazol pada tinggi tanaman ubi kayu klon Kasetsart umur 13 dan 15 MST pada Tabel 2.

Tabel 2. Hasil nilai tengah aplikasi beberapa konsentrasi paclobutrazol pada tinggi tanaman ubi kayu klon Kasetsart umur 13 dan 15 MST.

\begin{tabular}{ccc}
\hline Konsentrasi & \multicolumn{2}{c}{ Tinggi Tanaman $(\mathrm{cm})$} \\
\cline { 2 - 3 } Paclobutrazol & $13 \mathrm{MST}$ & $15 \mathrm{MST}$ \\
\hline $0 \mathrm{ppm}$ & $165,63 \mathrm{a}$ & $198,94 \mathrm{a}$ \\
$400 \mathrm{ppm}$ & $126,88 \mathrm{~b}$ & $148,38 \mathrm{~b}$ \\
$500 \mathrm{ppm}$ & $128,13 \mathrm{~b}$ & $149,00 \mathrm{~b}$ \\
$600 \mathrm{ppm}$ & $128,56 \mathrm{~b}$ & $147,56 \mathrm{~b}$ \\
\hline BNT 5\% & 10,34 & 13,76 \\
\hline
\end{tabular}

Keterangan: nilai tengah yang diikuti huruf yang sama pada kolom yang sama tidak berbeda nyata menurut uji BNT pada $\alpha=5 \%$.

Hasil uji lanjutan pada nilai tengah perlakuan dengan paclobutrazol terhadap pertumbuhan tinggi tanaman pada 13 dan 15 MST berbeda nyata dengan kontrol (tanpa paclobutrazol). Nilai tengah terendah 
yaitu 126,88 cm pada 13 MST ada pada perlakuan $400 \mathrm{ppm}$ paclobutrazol. Seiring bertambahnya waktu 2 minggu kemudian nilai tengah terendah terjadi pada perlakuan $600 \mathrm{ppm}$ dengan nilai 147,56 cm, walaupun tidak berbeda nyata dengan konsentrasi $400 \mathrm{ppm}$ dan $500 \mathrm{ppm}$ (Tabel 2). Laju pertumbuhan tinggi tanaman dari 8 MST sampai minggu ke-18 menunjukkan penghambatan pertumbuhan setelah aplikasi paclobutrazol 60 HST atau sekitar 9 MST (Gambar 1).

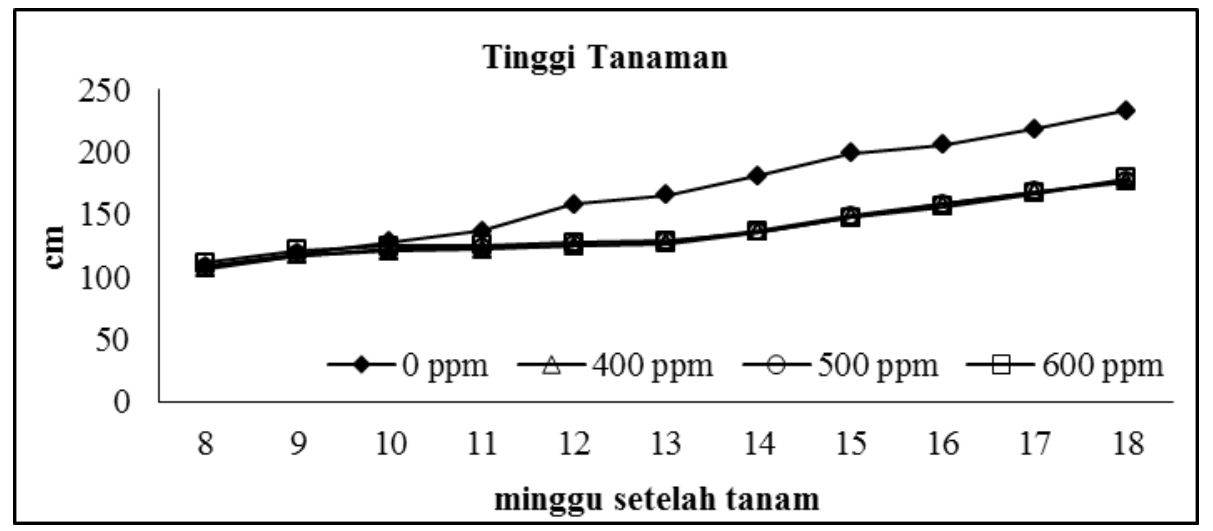

Gambar 1. Grafik tinggi tanaman ubi kayu klon Kasetsart umur 8 sampai dengan 15 MST pada berbagai konsentrasi paclobutrazol.

Jumlah Buku. Pengamatan dari hasil nilai tengah dari aplikasi beberapa konsentrasi paclobutrazol pada jumlah buku tanaman ubi kayu klon Kasetsart umur 13 dan 15 MST pada Tabel 3.

Tabel 3. Hasil nilai tengah aplikasi beberapa konsentrasi paclobutrazol pada jumlah buku tanaman ubi kayu klon Kasetsart 13 dan 15 MST

\begin{tabular}{ccc}
\hline \multirow{2}{*}{ Konsentrasi Paclobutrazol } & \multicolumn{3}{c}{ Jumlah Buku (tangkai) } \\
\cline { 2 - 3 } & $13 \mathrm{MST}$ & $15 \mathrm{MST}$ \\
\hline $0 \mathrm{ppm}$ & $67,81 \mathrm{a}$ & $84,81 \mathrm{a}$ \\
$400 \mathrm{ppm}$ & $60,50 \mathrm{~b}$ & $72,56 \mathrm{~b}$ \\
$500 \mathrm{ppm}$ & $56,63 \mathrm{~b}$ & $72,88 \mathrm{~b}$ \\
$600 \mathrm{ppm}$ & $58,88 \mathrm{~b}$ & $72,56 \mathrm{~b}$ \\
\hline BNT 5\% & 6,85 & 9,27 \\
\hline
\end{tabular}

Keterangan: nilai tengah yang diikuti huruf yang sama pada kolom yang sama tidak berbeda nyata menurut uji BNT pada $\alpha=5 \%$.

Hasil uji lanjutan dengan BNT 5\% menunjukkan bahwa perlakuan paclobutrazol untuk konsentrasi 400 ppm sampai dengan 600 ppm tidak berbeda nyata, namun berbeda nyata dengan perlakuan kontrol. Pada peubah jumlah buku umur 13 MST nilai tengah terendah yaitu 56,63 dicapai pada 500 ppm paclobutrazol dan pada umur 15 MST dicapai pada konsentrasi 400 dan 600 ppm paclobutrazol dengan jumlah yang sama yaitu 72,56 (Tabel 3).

Laju pertumbuhan jumlah buku tanaman dari 8 minggu setelah tanam sampai minggu ke-18 mempunyai kecenderungan yang mirip dengan pertumbuhan tinggi tanaman yang menunjukkan penghambatan pertumbuhan setelah aplikasi paclobutrazol 60 hari setelah tanam. Pengaruhnya jelas baru terlihat setelah umur 12 minggu setelah tanam atau 3 minggu setelah aplikasi paclobutrazol (Gambar 2). 
Ardian, dkk : Pengaruh Aplikasi Beberapa Konsentrasi Paclobutrazol dan Koh Terhadap

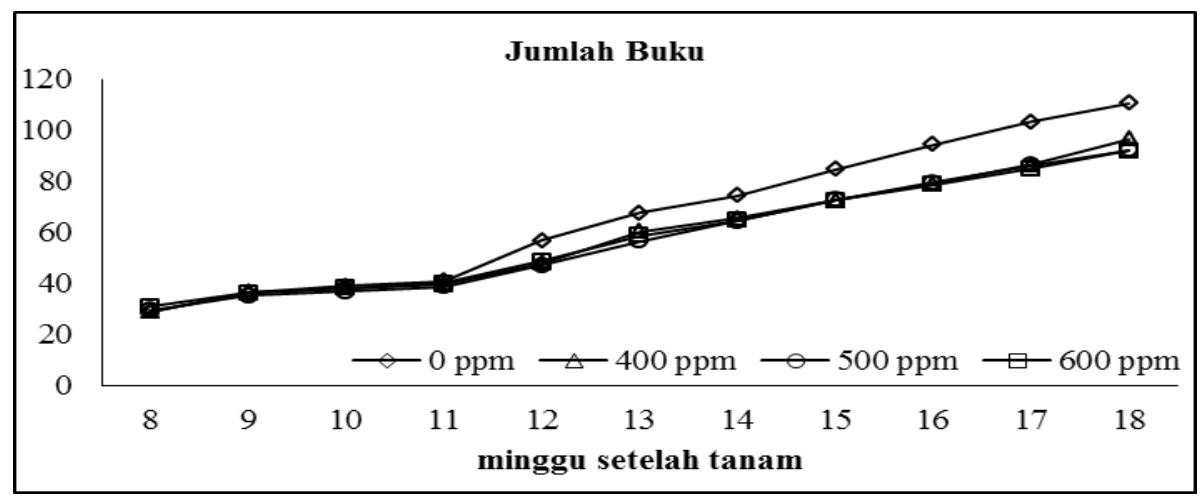

Gambar 2. Grafik jumlah buku tanaman ubi kayu klon Kasetsart umur 8 sampai dengan 15 MST pada berbagai konsentrasi paclobutrazol.

Jumlah Daun Segar. Pengamatan dari hasil nilai tengah dari aplikasi beberapa konsentrasi KOH pada jumlah daun segar tanaman ubi kayu klon Kasetsart umur 13 MST pada Tabel 4.

Tabel 4. Hasil nilai tengah aplikasi beberapa konsentrasi KOH pada jumlah daun segar tanaman ubi kayu klon Kasetsart 13 MST

\begin{tabular}{cc}
\hline Konsentrasi $\mathrm{KOH}$ & Jumlah Daun Segar (helai) 13 MST \\
\hline $0 \%$ & $8,3 \mathrm{a}$ \\
$0,5 \%$ & $6,3 \mathrm{ab}$ \\
$1 \%$ & $4,3 \mathrm{~b}$ \\
$1,5 \%$ & $3,0 \mathrm{~b}$ \\
\hline BNT $5 \%$ & 2,89 \\
\hline
\end{tabular}

Keterangan: nilai tengah yang diikuti huruf yang sama pada kolom yang sama tidak berbeda nyata menurut uji BNT pada $\alpha=5 \%$.

Hasil analisis lanjutan pada nilai tengah jumlah daun segar menunjukkan semakin tinggi konsentrasi $\mathrm{KOH}$ yang diberikan, jumlah daun segar semakin rendah. Jumlah daun segar pada perlakuan 0\% sampai 1,5\% menurun drastis, pada konsentrasi $1 \%$ dan 1,5\% berbeda nyata dengan kontrol, tetapi tidak berbeda nyata dengan $0,5 \% \mathrm{KOH}$ (Tabel 4 ).

Grafik menunjukkan bahwa aplikasi beberapa kosentrasi $\mathrm{KOH}$ melalui daun menghasilkan pertumbuhan jumlah daun segar yang semakin menurun, namun pada minggu ke-13 setelah aplikasi $\mathrm{KOH}$ jumlah daun segar meningkat kembali. Akan tetapi menurun kembali pada minggu ke-16 (Gambar 3). Hal ini kemungkinan berkaitan dengan curah hujan yang banyak pada minggu 13 dan 15 MST (Gambar 3).

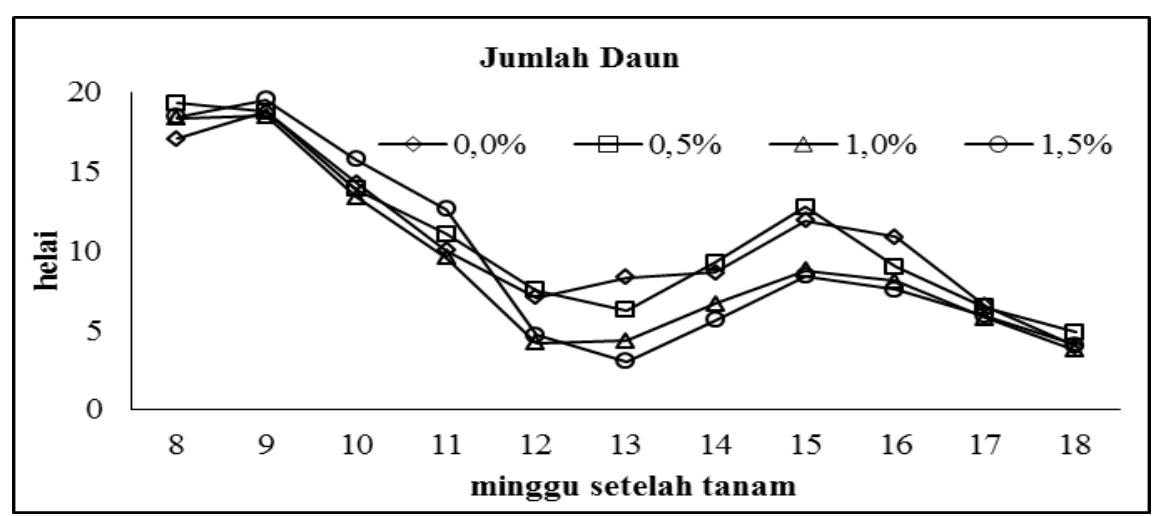

Gambar 3. Grafik jumlah daun segar tanaman ubi kayu klon Kasetsart umur 8 sampai dengan 18 MST pada berbagai konsentrasi $\mathrm{KOH}$. 
Jurnal Penelitian Pertanian Terapan

Bobot Segar dan Bobot Kering. Hasil uji lanjutan terhadap peubah bobot kering daun, bobot basah batang dan bobot kering batang ubi kayu klon Kasersart dapat dilihat Tabel 5.

Tabel 5. Hasil uji lanjutan nilai tengah interaksi antar perlakuan paclobutrazol dan $\mathrm{KOH}$ pada bobot kering daun tanaman ubi kayu 5 BST.

\begin{tabular}{lcccc}
\hline \multirow{2}{*}{ Konsentrasi KOH } & \multicolumn{4}{c}{ Bobot Kering Daun $(\mathrm{g})$} \\
\cline { 2 - 5 } & \multicolumn{4}{c}{$500 \mathrm{ppm}$} \\
\cline { 2 - 5 } & $0 \mathrm{ppm}$ & $400 \mathrm{ppm}$ & $600 \mathrm{ppm}$ \\
\hline $0 \%$ & $57,33 \mathrm{a}$ & $19,58 \mathrm{c}$ & $37,35 \mathrm{~b}$ & $54,95 \mathrm{a}$ \\
& $\mathrm{x}$ & $\mathrm{z}$ & $\mathrm{y}$ & $\mathrm{x}$ \\
$0,5 \%$ & $40,43 \mathrm{ab}$ & $56,13 \mathrm{a}$ & $45,35 \mathrm{ab}$ & $48,28 \mathrm{ab}$ \\
& $\mathrm{y}$ & $\mathrm{y}$ & $\mathrm{xy}$ & $\mathrm{xy}$ \\
$1 \%$ & $66,80 \mathrm{a}$ & $57,10 \mathrm{ab}$ & $51,50 \mathrm{~b}$ & $37,23 \mathrm{c}$ \\
& $\mathrm{x}$ & $\mathrm{y}$ & $\mathrm{x}$ & $\mathrm{y}$ \\
$1,5 \%$ & $60,95 \mathrm{ab}$ & $71,50 \mathrm{a}$ & $35,33 \mathrm{c}$ & $47,08 \mathrm{bc}$ \\
& $\mathrm{x}$ & $\mathrm{x}$ & $\mathrm{y}$ & $\mathrm{xy}$ \\
\hline BNT 5\% & & 13,90 & & \\
\hline
\end{tabular}

Keterangan: nilai tengah yang diikuti huruf yang sama pada kolom yang sama dan huruf yang sama pada baris yang sama tidak berbeda nyata menurut uji BNT pada $\alpha=5 \%$.

Hasil penelitian menunjukkan bahwa interaksi perlakuan paclobutrazol dan $\mathrm{KOH}$ berpengaruh nyata terhadap bobot kering daun. Pemberian $400 \mathrm{ppm}$ paclobutrazol dan 1,5\% $\mathrm{KOH}$ menunjukkan nilai tengah yang tertinggi dibandingkan konsentrasi lainnya yaitu 66,80 g. Perlakuan 500 ppm paclobutrazol menghasilkan nilai bobot kering daun yang lebih rendah pada setiap konsentrasi $\mathrm{KOH}$, dan perlakuan berbagai konsentrasi $\mathrm{KOH}$ menunjukkan bobot kering daun yang lebih tinggi dibandingkan tanpa $\mathrm{KOH}$ (kontrol) (Tabel 5). Hasil yang sama juga terlihat pada peubah bobot kering batang dengan nilai terendah sebesar 145,79 g pada perlakuan 500 ppm.

Hasil uji lanjutan pada nilai tengah menunjukkan bahwa perlakuan paclobutrazol berpengaruh nyata terhadap bobot basah dan kering batang dapat dilihat pada Tabel 6 .

Tabel 6. Hasil nilai tengah aplikasi beberapa konsentrasi paclobutrazol melalui daun pada bobot segar batang 5 BST

\begin{tabular}{ccc}
\hline Konsentrasi & Bobot Segar Batang $(\mathrm{g} / \tan )$ & Bobot Kering Batang $(\mathrm{g} / \tan )$ \\
Paclobutrazol & & \\
\hline $0 \mathrm{ppm}$ & $812,21 \mathrm{a}$ & $241,16 \mathrm{a}$ \\
$400 \mathrm{ppm}$ & $606,70 \mathrm{~b}$ & $160,84 \mathrm{~b}$ \\
$500 \mathrm{ppm}$ & $515,93 \mathrm{~b}$ & $145,79 \mathrm{~b}$ \\
$600 \mathrm{ppm}$ & $549,49 \mathrm{~b}$ & $152,73 \mathrm{~b}$ \\
\hline BNT 5 \% & 145,19 & 43,20 \\
\hline
\end{tabular}

Keterangan: nilai tengah diikuti huruf yang sama tidak berbeda nyata menurut uji $\mathrm{BNT} \alpha=5 \%$

Pada peubah bobot segar batang semakin tinggi konsentrasi paclobutrazol menurunkan bobot segar batang dan berbeda nyata dengan kontrol. Nilai terendah bobot segar batang 515,93 g pada perlakuan 500 ppm yang menunjukkan konsentrasi ini paling menghambat pertumbuhan batang (Gambar 4). 


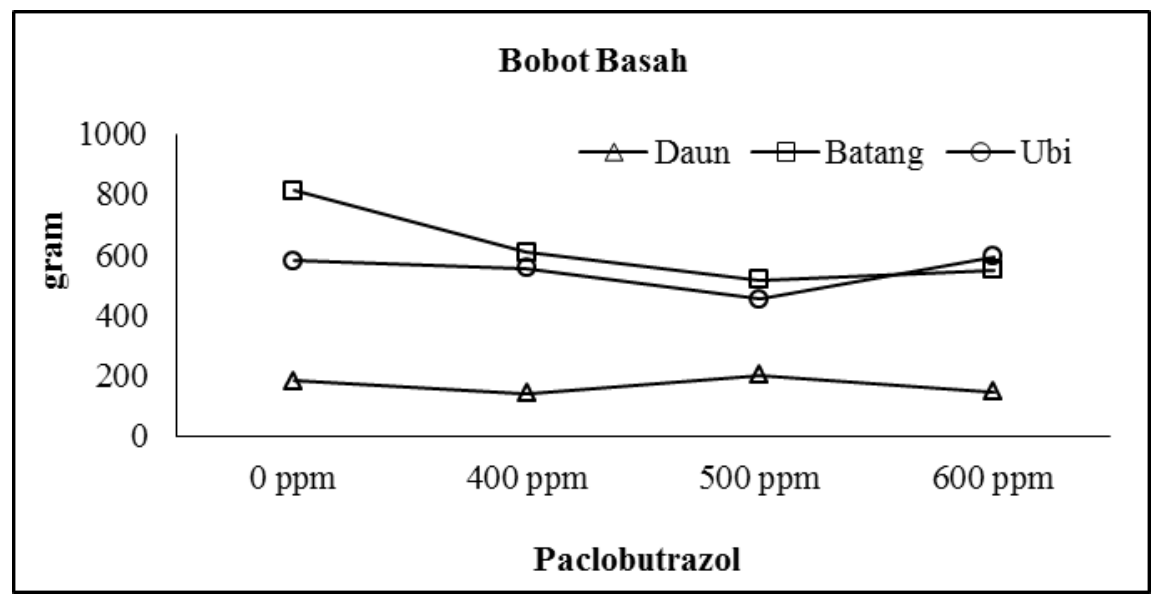

Gambar 4. Grafik bobot segar daun, batang dan ubi pada berbagai konsentrasi paclobutrazol.

Perlakuan paclobutrazol tidak mempengaruhi atau nilai tengah antar perlakuan tidak berbeda nyata pada peubah bobot daun, bobot kering daun, bobot segar ubi dan bobot kering ubi (Gambar 5)

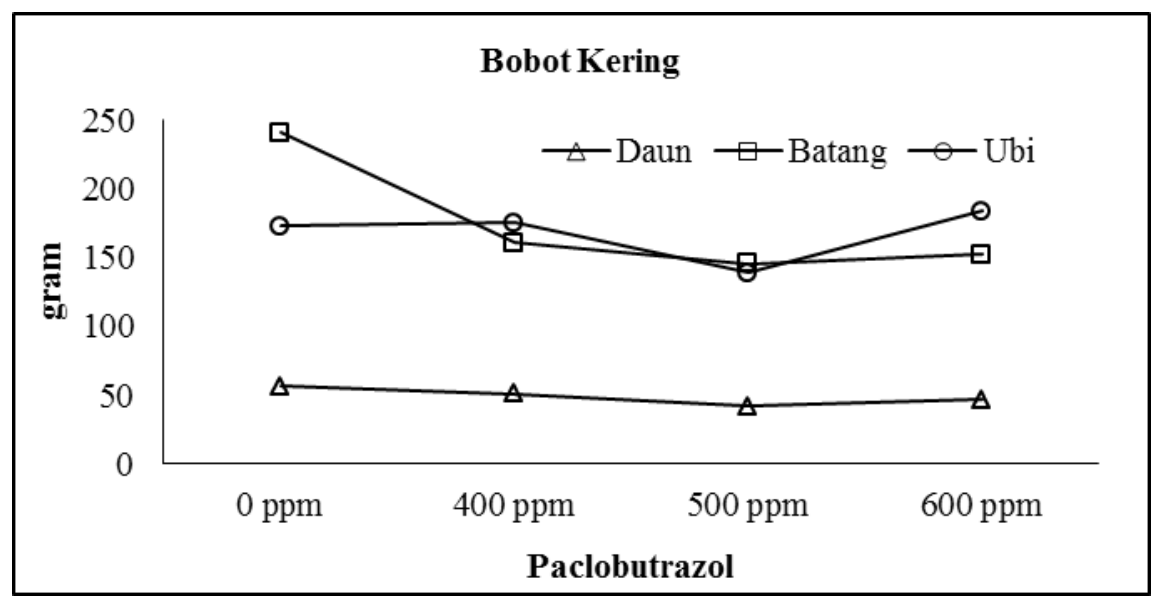

Gambar 5. Grafik bobot kering daun, batang dan ubi pada berbagai konsentrasi paclobutrazol.

Perlakuan $\mathrm{KOH}$ tidak mempengaruhi atau nilai tengah antar perlakuan tidak berbeda nyata pada semua peubah bobot segar dan bobot kering. Begitu juga interaksi perlakuan paclobutazol dan $\mathrm{KOH}$ tidak mempengaruhi atau nilai tengah antar perlakuan tidak berbeda nyata pada semua peubah bobot segar daun, batang dan ubi, serta bobot kering batang dan ubi.

Berdasarkan hasil penelitian yang telah dilakukan, diketahui bahwa perlakuan berbagai konsentrasi paclobutrazol dan $\mathrm{KOH}$ maupun interaksinya menghambat pertumbuhan vegetatif tanaman maupun bagian penyimpanan (sink) yaitu tinggi tanaman, jumlah buku, jumlah daun segar, bobot segar dan kering daun, bobot segar dan kering batang, dan bobot segar dan kering ubi. Beberapa penelitian lain melaporkan pengaruh yang mirip dengan penelitian ini, pemberian paclobutrazol dapat menghambat pertumbuhan pucuk dan akar tanaman jeruk satsuma mandarin (Poerwanto, 1994), menghambat pertumbuhan tanaman kentang (Balamani, 1985), dan menghambat tinggi tanaman tomat (Berova, 2000). Aplikasi paclobutrazol pada tanaman kentang saat 28 hari setelah tanam dapat mengurangi panjang batang, jumlah umbi pertanaman, kandungan gula kentang dan meningkatkan kandungan pati (Mabvongwe O., B. T. Manenji., M. Gwazane, 2016). Paclobutrazol pada konsentrasi yang tinggi (10 dan $20 \mathrm{mg} / \mathrm{l}$ ) beracun bagi tanaman anggrek Arundina graminifolia dan mematikan tanaman, tetapi pada konsentrasi yang rendah $(5 \mathrm{mg} / \mathrm{l})$ dapat mengendalikan tinggi tanaman (Wanderley, C.S., R. T. deFaria., 2014). Penghambatan pertumbuhan tanaman oleh 
paclobutrazol terjadi karena zat ini menghambat biosintesis giberelin dengan menghalangi perubahan ent kaurene ke asam ent kaurenoic (Setia, R.C., P. Kaur, 1996).

Aplikasi $\mathrm{KOH}$ pada daun tanaman ubi kayu varietas Kasetsart tidak berpengaruh nyata pada semua peubah yang diamati kecuali peubah jumlah daun segar umur 13 MST atau 31 hari setelah aplikasi. Hal ini diduga karena unsur $\mathrm{K}$ dalam tanaman berbentuk ion $(\mathrm{K}+$ ), yang menjadikan $\mathrm{K}$ bersifat mobile dalam tubuh tanaman (mudah bergerak), sehingga $\mathrm{K}$ berperan untuk memacu translokasi hasil fotosintesis dari daun ke bagian lain. Penimbunan fotosintat di dalam daun menghambat fotosintesis, karena pemindahannya keluar daun dapat mempertahankan laju fotosintesis yang tinggi (Supandie, 1997). Laju fotosintesis yang tinggi akan melancarkan suplai makanan (hasil fotosintesis) ke seluruh bagian tanaman sehingga hal ini dapat memacu pertumbuhan dan produksi tanaman (Lakitan, 2004).

\section{KESIMPULAN}

Perlakuan paclobutrazol berpengaruh nyata dalam menghambat pertumbuhan vegetatif tinggi tanaman dan jumlah buku, bobot segar dan bobot kering batang tanaman ubi kayu. Aplikasi $\mathrm{KOH}$ memberikan pengaruh nyata pada jumlah daun segar 13 MST. Semakin tinggi konsentrasi KOH yang diberikan, semakin rendah jumlah daun segar tanaman ubi kayu. Interaksi perlakuan paclobutrazol dan $\mathrm{KOH}$ memberikan pengaruh nyata pada bobot kering daun Perlakuan 400 ppm paclobutrazol dan 1,5\% KOH menunjukkan nilai bobot kering daun tertinggi yaitu 71,50 helai. Nilai bobot ubi tertinggi dicapai pada interaksi $600 \mathrm{ppm}$ paclobutrazol dan $1,5 \% \mathrm{KOH}$.

\section{DAFTAR PUSTAKA}

Balamani, V. and B. W. P. (1985). Retardation of shoot growth and promotion of tuber growth of potato plants bypaclobutrazol. Am.Pot.J, 62, 363-369.

Berova, M. and Z. Z. (2000). Physiological response and yield of paclobutrazol treated tomato plants (Lycopersicon esculentum Mill.). Plant Growth Reg, 30, 117-123.

Hafsah, M. J. (2003). Bisnis Ubi Kayu Indonesia. Pustaka Sinar Harapan.

Lakitan, B. (2004). Dasar-dasar Fisiologi Tumbuhan. PT. Raja Grafindo Persada.

Mabvongwe O., B. T. Manenji., M. Gwazane, and M. C. (2016). The Effect of Paclobutrazol Application Time and Variety on Growth, Yield, and Quality of Potato (Solanum tuberosum L.). https://doi.org/Advances in Agriculture

Poerwanto, R. dan H. I. (1994). Pengaruh paclobutrazol terhadap pertumbuhan dan pembungaan jeruk satsuma mandarin pada beberapa kondisi suhu. Bul. Agron, 22, 55-67.

Poerwanto, R, Harjadi, SS, Susanto, S, Purwoko, BS, Widodo, WD \& Effendi, D. (1995). Studi tentang pertumbuhan dan perkembangan pohon buah-buahan tropis, guna memperpendek masa tanaman sebelum menghasilkan dan menginduksi pembungaan. Institut Pertanian Bogor.

Runtunuwu, S. D., P. Tumewu, D.M.F. Sumampouw, S. Walingkas, dan A. R. (2013). Penggunaan Retardan untuk Meningkatkan Produksi Padi Sawah. Unsrat.

Salisbury, F. B. dan C. W. R. (2002). Plant Physiology. Wadsworth Publishing Company.

Setia, R.C., P. Kaur, N. S. and A. (1996). Infuence of paclobutrazol on growth and development of fruit in Brassica juncea (L.) Czern and Coss. Plant Growth Reg, 20, 307-316.

Simanjuntak, D. (2006). Pemanfaatan Komoditas Non Beras dalam Diversifikasi Pangan Sumber Kalori. J. Penelitian Bid. I. Pertanian, 4(1), 116-123. 
Ardian, dkk : Pengaruh Aplikasi Beberapa Konsentrasi Paclobutrazol dan Koh Terhadap

Soetanto. (2001). Pengolahan Singkong. Balai Pustaka dan Media Wiyata.

Supandie, D. (1997). Fungsi dan Metabolisme Hara Serta Hubungannya dengan Produksi Tanaman. Institut Pertanian Bogor.

Wanderley, C.S., R. T. deFaria., M. U. V. and W. V. (2014). The effect of plant growth regulators on height control in potted Arundina graminifolia orchids (Growthregulators in Arundina graminifolia). Acta Scientiarum, 36(4), 489-494.

Yuliadi, E., Sunyoto., Kristina, A. dan A. (2011). Aplikasi Paclobutrazol Melalui Daun Tanaman Ubi kayu (Manihot esculenta Crantz.) untuk Merangsang Pembungaan Dini di Dataran Rendah. Jurnal Penelitian Pertanian Terapan, 12(1), 50-57. 